\title{
Saccharothrix violacea sp. nov., isolated from a gold mine cave, and Saccharothrix albidocapillata comb. nov.
}

\author{
Soon Dong Lee, ${ }^{1}$ Eun Suk Kim, ${ }^{1}$ Jung-Hye Roe, ${ }^{1}$ Jae-heon Kim, ${ }^{2}$ \\ Sa-Ouk Kang ${ }^{1}$ and Yung Chil Hah ${ }^{1}$
}
1 Department of Microbiology, College of Natural Sciences and Research Center for Molecular Microbiology, Seoul National University, Seoul 151-742, Republic of Korea
2 Department of Microbiology, College of Natural Sciences, Dan Kook University, Cheon An 330-180, Republic of Korea

\author{
Author for correspondence: Yung Chil Hah. Tel: +82 2880 6700. Fax: +82 28884911 \\ e-mail: hahyungc@snu.ac.kr
}

\begin{abstract}
The generic position of two isolates from soils inside a gold mine cave in Kongju, Korea, was determined by $16 \mathrm{~S}$ rDNA sequencing and chemotaxonomic characteristics. Phylogenetic analysis indicated that both of the isolates formed a clade with Lentzea albidocapillata and members of the genus Saccharothrix of the family Pseudonocardiaceae. The chemical composition of the isolates and of Lentzea albidocapillata was consistent with that of the genus Saccharothrix, which is characterized by a type III cell wall (the mesoisomer of diaminopimelic acid, and galactose and rhamnose as characteristic whole-cell sugars), $\mathrm{MK}-9\left(\mathrm{H}_{4}\right)$ as the major menaquinone, and a phospholipid type PII pattern (phosphatidylethanolamine as a diagnostic phospholipid). The combination of morphological features, chemotaxonomic characters and phylogenetic data supported the proposal that Lentzea albidocapillata, the only and type strain of the genus Lentzea, should be transferred to the genus Saccharothrix. On the basis of physiological properties, cellular fatty acid composition and DNA-DNA hybridization data, two new species within the genus Saccharothrix are proposed: Saccharothrix violacea sp. nov., type strain LM $036^{\top}$ ( = IMSNU 50388'), and Saccharothrix albidocapillata comb. nov., type strain DSM 44073' (= IMSNU 21253').
\end{abstract}

Keywords: Saccharothrix violacea sp. nov., Saccharothrix albidocapillata comb. nov., soil bacteria, phylogeny

\section{INTRODUCTION}

The genus Saccharothrix was described by Labeda et al. (1984) for amycolate actinomycetes that are characterized by fragmentation of both the vegetative and aerial mycelia into ovoid elements and the following cell chemistry: a type III cell wall (the meso-isomer of diaminopimelic acid, and rhamnose and galactose as whole-cell sugars); absence of mycolic acids; a major menaquinone of MK- $9\left(\mathrm{H}_{4}\right)$; and a phospholipid type PII (phosphatidylethanolamine) or PIV (phosphatidylethanolamine and glucosamine-containing phospholipids) pattern (Labeda \& Lechevalier, 1989). The genus currently contains 12 described species: Saccharothrix aerocolonigenes, Saccharothrix aus-

Abbreviation: ISP, International Streptomyces Project.

The EMBL accession numbers for the 165 rDNA nucleotide sequences of isolates LM $036^{\top}$ and LM 044 are AJ242633 and AJ242634, respectively. traliensis, Saccharothrix coeruleofusca, Saccharothrix coeruleoviolacea, Saccharothrix cryophilis, Saccharothrix espanaensis, Saccharothrix flava, Saccharothrix longispora, Saccharothrix mutabilis, Saccharothrix syringae, Saccharothrix texasensis and Saccharothrix waywayandensis (Labeda \& Lechevalier, 1989; Grund \& Kroppenstedt, 1989).

Yassin et al. (1995) proposed Lentzea albidocapillata gen. nov., sp. nov. for a mesophilic actinomycete which forms a well-developed, fragmenting aerial mycelium and a branched substrate mycelium. The genus Lentzea has a type III cell wall (meso-isomer of diaminopimelic acid and no characteristic sugar), phosphatidylethanolamine as a diagnostic phospholipid (the phospholipid type PII pattern) and a nonhydrogenated menaquinone with nine isoprene units (MK-9) as a major menaquinone. This genus currently contains the only and type species, Lentzea albidocapillata, which was isolated from a tissue specimen 
taken from a patient suffering from peritoneal carcinomatosis.

The family Pseudonocardiaceae Embley et al. 1988 was recently emended by Stackebrandt et al. (1997), based on the 16S-rDNA-sequence-based phylogenetic clustering and the presence of family-specific signature nucleotides. According to cell wall chemotype, the 13 genera of the family Pseudonocardiaceae are divided into two groups as follows: the type IV cell wall genera comprise Actinokineospora, Actinopolyspora, Amycolatopsis, Kibdelosporangium, Pseudonocardia, Saccharomonospora and Saccharopolyspora (Warwick et al., 1994), whereas the type III cell wall genera comprise Actinosynnema (Hasegawa et al., 1978), Kutzneria (Stackebrandt et al., 1994), Lentzea (Yassin et al., 1995), Saccharothrix (Labeda et al., 1984), Streptoalloteichus (Tomita et al., 1987) and Thermocrispum (Korn-Wendisch et al., 1995). The type III cell wall genera and the genus Actinokineospora, a member of the type IV cell wall genera, form a coherent cluster within the radiation of the family Pseudonocardiaceae (Lee et al., 2000b; Yassin et al., 1995).

During the taxonomic study of soil actinomycetes, we obtained two isolates from soils collected inside a gold mine cave in Kongju, Republic of Korea. Both of the isolates formed well-developed aerial mycelia that fragmented into rod-shaped elements. The comparative analysis of $16 \mathrm{~S}$ rDNA sequences supported the conclusion that our isolates were related to members of the genera Lentzea and Saccharothrix. In this paper we describe the characterization and classification of the isolates, and we propose the new taxa Saccharothrix violacea sp. nov. and Saccharothrix albidocapillata comb. nov. The isolates LM $036^{\mathrm{T}}$ and LM 044 have been deposited in the Culture Collection Center of the Institute of Microbiology, Seoul National University (IMSNU) under the numbers IMSNU $50388^{\mathrm{T}}$ and IMSNU 50393, respectively.

\section{METHODS}

Micro-organisms and culture conditions. Strains LM $036^{\mathrm{T}}$ and LM 044 were isolated from soils collected inside a gold mine cave in Kongju, Korea, on tap water agar and oligotrophic medium (M5) by using the dilution plating method. The M5 medium contained (per litre of tap water) glucose, $0.1 \mathrm{~g} ; \mathrm{K}_{2} \mathrm{HPO}_{4}, 0.5 \mathrm{~g} ; \mathrm{Na}_{2} \mathrm{HPO}_{4}, 0.7 \mathrm{~g} ; \mathrm{KNO}_{3}$, $0.1 \mathrm{~g} ; \mathrm{NaCl}, 0.3 \mathrm{~g} ; \mathrm{MgSO}_{4} \cdot 7 \mathrm{H}_{2} \mathrm{O}, 0.1 \mathrm{~g} ; \mathrm{CaCl}_{2} \cdot 2 \mathrm{H}_{2} \mathrm{O}$, $0.02 \mathrm{~g} ; \mathrm{FeSO}_{4} .7 \mathrm{H}_{2} \mathrm{O}, 200 \mathrm{mg} ; \mathrm{ZnSO}_{4} .7 \mathrm{H}_{2} \mathrm{O}, 180 \mu \mathrm{g}$; $\mathrm{MnSO}_{4} \cdot 4 \mathrm{H}_{2} \mathrm{O}, 20 \mu \mathrm{g} ; \mathrm{CuSO}_{4} .5 \mathrm{H}_{2} \mathrm{O}, 90 \mu \mathrm{g} ; \mathrm{CoSO}_{4} .7 \mathrm{H}_{2} \mathrm{O}$, $10 \mu \mathrm{g} ; \mathrm{H}_{3} \mathrm{BO}_{3}, 200 \mu \mathrm{g}$; and $\left(\mathrm{NH}_{4}\right)_{6} \mathrm{Mo}_{7} \mathrm{O}_{24} \cdot 4 \mathrm{H}_{2} \mathrm{O}, 5 \mu \mathrm{g}$. For comparative purposes, Lentzea albidocapillata IMSNU $21253^{\mathrm{T}}$ (=DSM 44073 ${ }^{\mathrm{T}}$ ) was used as a reference strain.

Morphological and cultural characteristics. The degree of growth, aerial mycelium, pigmentation and other morphological features were investigated on yeast extract/malt extract agar [International Streptomyces Project (ISP) medium 2], oatmeal agar (ISP medium 3) and inorganic salts/starch agar (ISP medium 4) as described by Shirling \& Gottlieb (1966), and on yeast extract/glucose agar. Melanin pigment production was determined using peptone/yeast extract/iron agar (ISP medium 6) and tyrosine agar (ISP medium 7). For scanning electron microscopy, agar blocks on which growth had occurred were fixed in $1 \%$ osmium tetroxide, dehydrated with an ethanol series and then critical-point-dried under liquid $\mathrm{CO}_{2}$. Each specimen was sputter-coated with gold and observed with a scanning electron microscope (Stereoscan 260; Cambridge Instruments).

Physiological characteristics. Utilization of carbohydrates and of organic acids as carbon sources was determined as described by Pridham \& Gottlieb (1948) and Gordon et al. (1974), respectively. Acid production from carbohydrates was determined by a colour change in Bacto OF basal medium (Difco) supplemented with the substrates at a final concentration of $1 \%(\mathrm{w} / \mathrm{v})$. Decomposition of adenine, guanine, hypoxanthine, tyrosine and xanthine were determined as described by Gordon et al. (1974), and arbutin and aesculin decomposition and casein hydrolysis were determined as described by Williams et al. (1983). Decomposition of DNA was determined using Bacto DNase test agar (Difco). Nitrate reduction, hydrogen sulfide production, gelatin liquefaction, starch hydrolysis and hippurate hydrolysis were studied as described by Mac Faddin (1980). Urease activity was determined by a colour change from red to pink in Bacto urea broth (Difco). Catalase activity was checked with $3 \%$ hydrogen peroxide. Oxidase production was tested by examining the oxidation of $1 \%$ tetramethyl-p-phenylenediamine. $\mathrm{NaCl}$ tolerance studies were performed on nutrient agar containing $\mathrm{NaCl}$ at final concentrations of $0,2,4,7$ and $10 \%(\mathrm{w} / \mathrm{v})$. Thallium acetate tolerance was determined on nutrient agar at a final concentration of $0.01 \%(\mathrm{w} / \mathrm{v})$. To determine sensitivity to lysozyme, a $0 \cdot 1 \%(\mathrm{w} / \mathrm{v})$ solution of lysozyme was filtersterilized and added to nutrient agar at a final concentration of $0.01 \%$. Growth was tested at temperatures ranging from 10 to $42^{\circ} \mathrm{C}$.

Growth in the presence of various antibiotics was tested using the standard disk diffusion technique (National Committee for Clinical Laboratory Standards, 1994). Disks containing the different antibiotics (Susceptibility test discs; Difco) were applied to Mueller-Hinton agar (Difco) plates which had been inoculated with $100 \mu \mathrm{l}$ mycelial suspension in $20 \%$ glycerol with a Dispense-O-Disc dispenser (Difco). The inverted plates were incubated for $7 \mathrm{~d}$ at $30{ }^{\circ} \mathrm{C}$.

To determine the production of antibiotic substances, the ability of the isolates to inhibit the growth of reference organisms was examined using an overlay technique (Williams et al., 1983). Reference organisms selected were Bacillus subtilis IMSNU 10011, Micrococcus luteus IMSNU 20371, Streptomyces murinus IMSNU 20248 ${ }^{\mathrm{T}}$, Staphylococcus aureus subsp. aureus IMSNU 11089, Escherichia coli IMSNU 10080, Enterobacter aerogenes IMSNU 10256, Saccharomyces cervisiae IMSNU 30102, Aspergillus niger IMSNU 31067 and Candida albicans IMSNU 30018. Spotinoculated cells of the isolates grown on nutrient agar for $7 \mathrm{~d}$ at $30{ }^{\circ} \mathrm{C}$ were overlaid with $5 \mathrm{ml}$ top agar $(0 \cdot 3 \%$ Bacto beef extract, $0.5 \%$ Bacto peptone, $0.5 \%$ Bacto agar) inoculated with the reference organisms. The degree of inhibition was observed after further incubation for $5 \mathrm{~d}$ at $30{ }^{\circ} \mathrm{C}$.

Chemotaxonomy. To determine cellular fatty acid compositions, test strains were cultivated in shake flasks containing trypticase soy broth $(\mathrm{BBL})$ at $30^{\circ} \mathrm{C}$ for $3 \mathrm{~d}$. Fatty acid methyl esters were extracted from the biomass as described by Minnikin (1988) and were analysed with a model 5890A Hewlett Packard gas chromatograph. The 
resultant peaks were identified by comparison with the Bacterial Acid Methyl Esters CP Mix (catalogue no. 1114; Matreya). Menaquinones were extracted by the method of Minnikin et al. (1984) and were analysed by using HPLC (Kroppenstedt, 1985) and a Quattro mass spectrometer (Micromass). The isomer of diaminopimelic acid was determined, and whole-cell sugar, mycolic acid and phospholipid analyses were performed, by the methods of Staneck \& Roberts (1974), Saddler et al. (1991), Minnikin et al. (1977, 1980, 1984) and Collins et al. (1982) as described previously (Lee et al., 2000a).

Isolation of DNA, determination of $\mathbf{G}+\mathbf{C}$ content and DNA-DNA hybridization. Genomic DNA was isolated and purified by the large-scale procedure of Hopwood et al. (1985). Test strains were grown on yeast extract/glucose broth for $3 \mathrm{~d}$ at $30^{\circ} \mathrm{C}$, harvested by centrifugation and washed twice with distilled water. The wet cells were immediately used for DNA isolation or kept at $-20^{\circ} \mathrm{C}$ until required. The $\mathrm{G}+\mathrm{C}$ content of purified DNA was determined by HPLC (Mesbah et al., 1989). DNA-DNA hybridization studies were carried out by the methods described by Hopwood et al. (1985). Genomic DNA was broken into fragments of $2-4 \mathrm{~kb}$ with an ultrasonic processor (Misonix) in ice-cold water. DNA was labelled with $\left[{ }^{32} \mathrm{P}\right] \mathrm{dATP}$ by the random-priming method (Sambrook et al., 1989). Unincorporated nucleotides were removed by passing the mixture through Sephadex G-50 filters. Heat-denatured reference DNA was blotted onto nylon membrane (Boehringer Mannheim) by using a Bio-Dot apparatus (BioRad) and cross-linked with an UV cross-linker (CL-1000; UVP). Denatured, labelled DNA was added to the hybridization mixture (Hopwood et al., 1985) and incubated at $55^{\circ} \mathrm{C}$ for $18 \mathrm{~h}$. The membranes were then washed twice with $2 \times \mathrm{SSC} / 0.01 \% \mathrm{SDS}$ for $15 \mathrm{~min}$ at $55^{\circ} \mathrm{C}$ and once with $2 \times \mathrm{SSC}$ at room temperature. The extent of hybridization on each dot was determined by using a scintillation counter (Hewlett Packard). Each hybridization value represents the mean of three replicates.

Phylogenetic analysis. PCR-mediated amplification and cloning of the $16 \mathrm{~S}$ rDNAs of the isolates LM $036^{\mathrm{T}}$ (=IMSNU 50388 ${ }^{\mathrm{T}}$ ) and LM 044 (=IMSNU 50393) were performed as described previously (Lee et al., 2000b). The purified, cloned 16S rDNA sequences were determined using the Cy5 AutoRead Sequencing kit (Pharmacia). The 16S rDNA sequences obtained were compared with those of representatives of the family Pseudonocardiaceae and aligned by using the CLUSTAL w program (Thompson et al., 1994). The evolutionary distance matrices were produced by using the method of Jukes \& Cantor (1969), and a phylogenetic tree was constructed by the neighbour-joining method (Saitou \& Nei, 1987) contained in the PHYLIP package (Felsenstein, 1993). Bootstrap analysis (Felsenstein, 1985) of the neighbour-joining data, using 1000 resamplings, was carried out for evaluating the reliability of tree topology.

Nucleotide sequence accession numbers. The reference sequences used in this study are available from the DDBJ, EMBL and GenBank nucleotide sequence databases under the following accession numbers: Actinobispora yunnanensis IMSNU 22019 ${ }^{\mathrm{T}}$, AJ252822; Actinosynnema mirum DSM $43827^{\mathrm{T}}$, X84447; Actinokineospora riparia IFO $14541^{\mathrm{T}}$, X76953; Amycolatopsis orientalis subsp. orientalis DSM $44040^{\mathrm{T}}$, X76958; Kibdelosporangium aridum subsp. aridum ATCC $39323^{\mathrm{T}}$, X53191; Kutzneria viridogrisea JCM $3282^{\mathrm{T}}$, U58530; Lentzea albidocapillata DSM 44073 ${ }^{\mathrm{T}}$, X84321; Pseudonocardia autotrophica IMSNU 20050" AJ252824;
Pseudonocardia saturnea IMSNU 20052 ${ }^{\mathrm{T}}$, AJ252829; Saccharomonospora azurea NA128 ${ }^{\mathrm{T}}$, Z38017; Saccharomonospora glauca DSM 43769 ${ }^{\mathrm{T}}$; Z38003; Saccharomonospora viridis NCIMB 9602 ${ }^{\mathrm{T}}$, Z38007; Saccharopolyspora gregorii NCIMB 12823 ${ }^{\mathrm{T}}$, X76962; Saccharopolyspora hirsuta subsp. hirsuta ATCC $27875^{\mathrm{T}}$, X53196; Saccharopolyspora rectivirgula ATCC 33515 ${ }^{\mathrm{T}}$, X53194; Saccharopolyspora taberi DSM 43856 ${ }^{\mathrm{T}}$, AF002819; Saccharothrix aerocolonigenes subsp. aerocolonigenes ISP 5034 ${ }^{\mathrm{T}}$, AB020030; Saccharothrix aerocolonigenes subsp. staurosporea JCM 9734, AB024287; Saccharothrix australiensis ATCC 31947 ${ }^{\mathrm{T}}$, X53194; Saccharothrix coeruleofusca DSM 43679 ${ }^{\mathrm{T}}$, X76963; Saccharothrix longispora DSM 43749 ${ }^{\mathrm{T}}$, X76964; Saccharothrix mutabilis subsp. capreolus DSM 40225 ${ }^{\mathrm{T}}$, X76965; Saccharothrix mutabilis subsp. mutabilis DSM 43853 ${ }^{\mathrm{T}}$, X76966; Saccharothrix waywayandensis $\mathrm{JCM}$ 9114 ${ }^{\mathrm{T}}$, AB020029; Thermocrispum agreste DSM $44070^{\mathrm{T}}$, X79183; Thermocrispum municipale DSM $44069^{\mathrm{T}}$, X79184.

The EMBL accession numbers for the 16S rDNA nucleotide sequences of isolates LM $036^{\mathrm{T}}$ and LM 044 are AJ242633 and AJ242634, respectively.

\section{RESULTS AND DISCUSSION}

\section{Morphological and cultural characteristics}

Both of the isolates exhibited good growth on all of the media tested and produced well-developed, white aerial mycelia that fragmented into rod-shaped elements (Figs 1 and 2). Other morphological features, such as sporangia, sclerotia and synnemata, were not observed. The isolates produced violet substrate mycelia and reddish-brown soluble pigments, whereas the substrate mycelium of the Lentzea albidocapillata reference strain was yellow-yellowish brown. Neither of the isolates produced melanin on either peptone/ yeast extract/iron agar (ISP medium 6) or tyrosine agar (ISP medium 7).

\section{Chemotaxonomic characteristics}

The diaminopimelic acid isomer and the sugar composition indicated that both the isolates had cell walls of type III (Lechevalier \& Lechevalier, 1970) (meso-diaminopimelic acid, galactose, mannose and rhamnose). The phospholipid profiles contained phosphatidylethanolamine, diphosphatidylglycerol, phosphatidylglycerol and phosphatidylinositol [phospholipid type PII pattern of Lechevalier et al. (1981)]. No mycolic acids were present. The major menaquinone of the isolates was MK-9 $\left(\mathrm{H}_{4}\right)(>80 \%$ of the total). Small amounts of MK-9 $\left(\mathrm{H}_{2}\right)$ and MK-9 $\left(\mathrm{H}_{6}\right)$ were also detected. The genus Lentzea has previously been reported to contain menaquinone MK-9 as the principal type (Yassin et al., 1995), whereas the major menaquinone of L. albidocapillata IMSNU $21253^{\mathrm{T}}$ determined in this study was MK-9 $\left(\mathrm{H}_{4}\right)(72 \%$ of total). The predominant fatty acid was iso-branched hexadecanoate $\left(\mathrm{i}-\mathrm{C}_{16: 0}\right)$. A significant amount of saturated, unsaturated, anteiso-branched and 10-methyl branched fatty acids were also present. Small amounts of tuberculostearic acid $\left(10 \mathrm{Me}-\mathrm{C}_{18: 0}\right)$ were present 

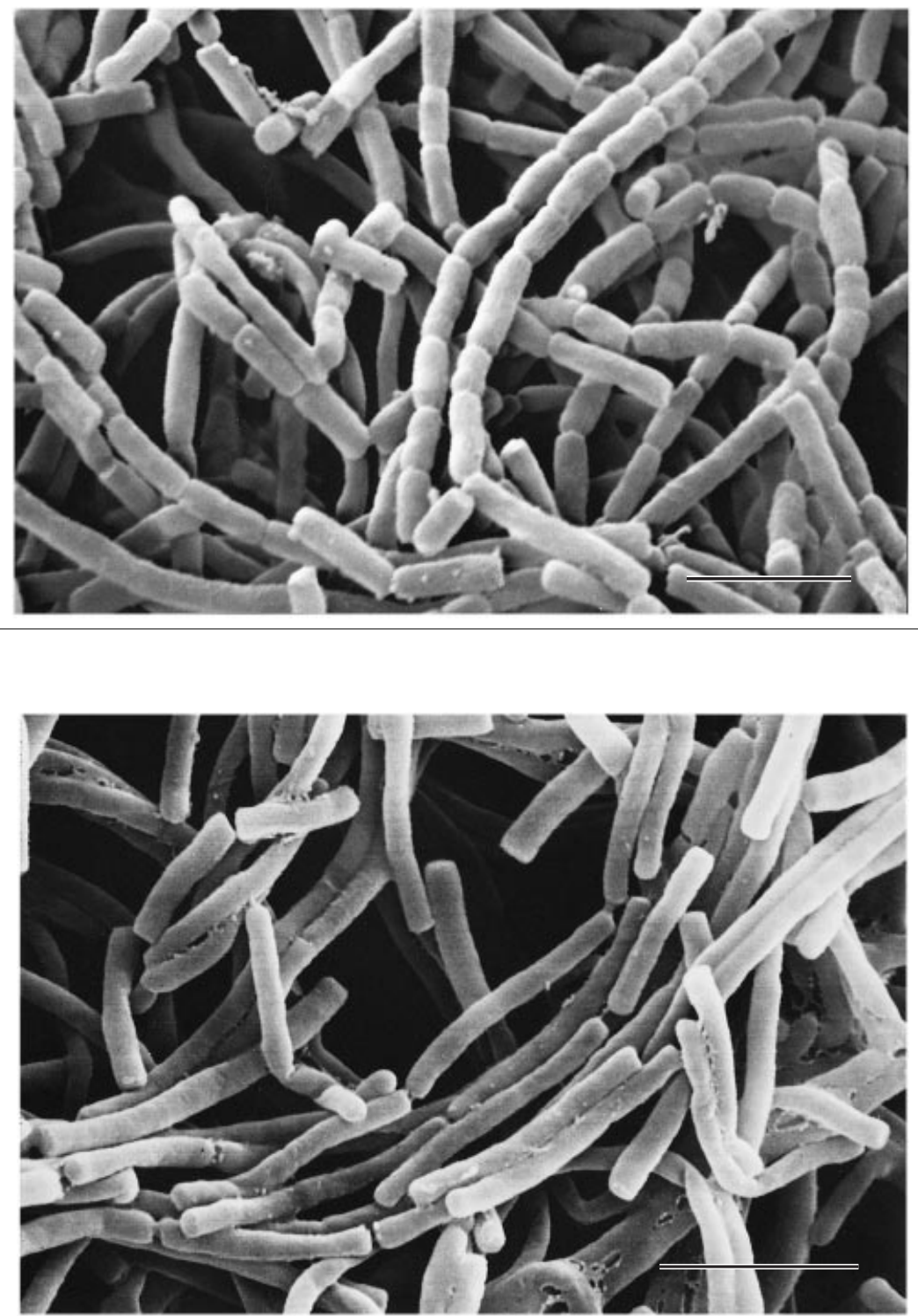

Fig. 1. Scanning electron micrograph of strain LM $036^{\top}$ (=IMSNU $50388^{\top}$ ) grown on ISP medium 4 (inorganic salts/starch agar). Bar, $2 \mu \mathrm{m}$ only in strain LM 044. The cellular fatty acid compositions of the isolates and L. albidocapillata are shown in Table 1.

\section{Physiological characteristics}

All of the test strains grew strictly aerobically. Catalase and urease were produced. Nitrate reductase and oxidase were not produced. $\mathrm{H}_{2} \mathrm{~S}$ was produced. Growth occurred between 20 and $37^{\circ} \mathrm{C}$. All of the test strains utilized L-arabinose, D-cellobiose, D-fructose, D-galactose, D-glucose, D-lactose, maltose, D-mannose, melibiose, L-rhamnose, sucrose, D-trehalose, D-xylose, adonitol, meso-inositol, D-mannitol, acetate, fumarate, $\alpha$-ketoglutarate, malonate, propionate, pyruvate and succinate as carbon sources. Arbutin, DNA, aesculin, hypoxanthine and tyrosine were decomposed. Casein, hippurate and starch were hydrolysed. All test strains showed acid production from L-arabinose, D-lactose and L-ribose. None of the test strains utilized inulin, D-melezitose, methyl $\alpha$-D-glucoside, methyl $\alpha$-Dmannoside, D-raffinose, dulcitol, 2,3-butanediol, mesoerythritol, 1,2-propanediol, D-sorbitol, D-xylitol, benzoate, citrate, formate, maleate or tartarate as carbon sources. Decomposition of adenine, guanine or xanthine, and acid production from D-mannose, melibiose, methyl $\alpha$-D-mannoside or salicin were not observed. All of the strains grew in the presence of $2 \% \mathrm{NaCl}$ and of $0.01 \%$ lysozyme.

All of the test strains were susceptible to $15 \mu \mathrm{g}$ erythromycin, $10 \mu \mathrm{g}$ gentamicin, $10 \mu \mathrm{g}$ kanamycin, $30 \mu \mathrm{g}$ neomycin, $30 \mu \mathrm{g}$ novobiocin, $5 \mu \mathrm{g}$ rifampicin, $10 \mu \mathrm{g}$ streptomycin, $30 \mu \mathrm{g}$ tetracycline and $10 \mu \mathrm{g}$ tobramycin, but were resistant to $10 \mu \mathrm{g}$ ampicillin and $2 \mu \mathrm{g}$ lincomycin.

Strain LM 044 showed antibiotic activity against Gram-positive bacteria, such as Bacillus subtilis, 
Table 1. Cellular fatty acid composition ( $\%$ of total fatty acids) of the new isolates and of the type strain of L. albidocapillata

Values of less than $0.5 \%$ are not shown.

\begin{tabular}{|c|c|c|c|}
\hline Fatty acid & $\begin{array}{c}\text { Strain } \\
\text { LM 036 }^{\mathrm{T}}\end{array}$ & $\begin{array}{l}\text { Strain } \\
\text { LM } 044\end{array}$ & $\begin{array}{l}\text { L. albidocapillata } \\
\text { IMSNU } 21253^{\mathrm{T}}\end{array}$ \\
\hline $\mathrm{C}_{12: 0}$ & $0 \cdot 6$ & & $1 \cdot 1$ \\
\hline $\mathrm{i}-\mathrm{C}_{14: 0}$ & $5 \cdot 6$ & $1 \cdot 8$ & $3 \cdot 9$ \\
\hline $\mathrm{C}_{14: 0}$ & $0 \cdot 6$ & & 1.9 \\
\hline $\mathrm{i}-\mathrm{C}_{15: 0}$ & $7 \cdot 0$ & $4 \cdot 6$ & $12 \cdot 5$ \\
\hline ai $-C_{15: 0}$ & $4 \cdot 2$ & $2 \cdot 3$ & $10 \cdot 4$ \\
\hline $\mathrm{C}_{15: 0}$ & & & $1 \cdot 8$ \\
\hline $\mathrm{i}-\mathrm{C}_{16: 1}$ & $2 \cdot 8$ & & $1 \cdot 9$ \\
\hline $\mathrm{i}-\mathrm{C}_{16: 0}$ & $42 \cdot 5$ & $35 \cdot 1$ & $28 \cdot 8$ \\
\hline$C_{16: 1}$ & $9 \cdot 6$ & $14 \cdot 9$ & $13 \cdot 5$ \\
\hline $\mathrm{C}_{16: 0}$ & $4 \cdot 2$ & $19 \cdot 4$ & $9 \cdot 4$ \\
\hline $\mathrm{i}-\mathrm{C}_{17: 1}$ & $0 \cdot 8$ & & $0 \cdot 6$ \\
\hline $10 \mathrm{Me}-\mathrm{C}_{16: 0}$ & $8 \cdot 0$ & $5 \cdot 3$ & $1 \cdot 4$ \\
\hline $\mathrm{i}-\mathrm{C}_{17: 0}$ & $0 \cdot 8$ & $2 \cdot 5$ & $0 \cdot 6$ \\
\hline$C_{17: 1}$ & $3 \cdot 6$ & $4 \cdot 4$ & $5 \cdot 7$ \\
\hline $\mathrm{C}_{17: 0}$ & & & $1 \cdot 0$ \\
\hline $10 \mathrm{Me}-\mathrm{C}_{17: 0}$ & $0 \cdot 5$ & & \\
\hline $\mathrm{i}-\mathrm{C}_{18: 0}$ & $1 \cdot 0$ & $1 \cdot 1$ & \\
\hline$C_{18: 1}$ & & $4 \cdot 3$ & \\
\hline $\mathrm{C}_{18: 0}$ & $3 \cdot 5$ & $3 \cdot 4$ & $2 \cdot 7$ \\
\hline $10 \mathrm{Me}-\mathrm{C}_{18: 0}$ & & $0 \cdot 7$ & \\
\hline
\end{tabular}

Micrococcus luteus, Streptomyces murinus and Staphylococcus aureus, and fungal organisms, such as Candida albicans, Saccharomyces cervisiae and Aspergillus niger.

The results of physiological tests differentiating the isolates and the type strain of L. albidocapillata are shown in Table 2.

\section{Phylogenetic analysis}

The almost complete 16S rDNA sequences, consisting of $97.7-97.8 \%$ of the $E$. coli sequence (Brosius et al., 1978), were determined for isolates LM 036 $\left(=\mathrm{IMSNU} 50388^{\mathrm{T}}\right)$ and LM 044 (=IMSNU 50393) and compared with those of representatives of the family Pseudonocardiaceae. A total of 1189 unambiguous nucleotide positions present in all sequences between 99 and 1470 (E. coli numbering) were used in final tree construction. The phylogenetic tree shown in Fig. 3 indicated that the isolates formed a clade with members of the genera Lentzea and Saccharothrix within the radiation encompassing the cell wall III type genera of the family Pseudonocardiaceae. This relationship was supported by a high bootstrap value of $79 \%$. The pairwise comparison of $16 \mathrm{~S}$ rDNA sequences indicated that the isolates exhibited the highest $16 \mathrm{~S}$ rDNA similarity values to $L$. albidocapillata $(98 \cdot 9 \pm 0 \cdot 1 \%)$, Saccharothrix waywayandensis $(98 \cdot 9 \pm 0 \cdot 1 \%)$ and Saccharothrix aerocolonigenes subsp. staurosporea $(98 \cdot 7 \pm 0 \cdot 1 \%)$. The sequence similarity value of the isolates was $99 \cdot 8 \%$. DNA-DNA hybridization studies revealed that the level of DNADNA relatedness between the isolates and the type strain of L. albidocapillata ranged from 40 to $46 \%$, whereas the isolates showed a DNA-DNA relatedness of $68 \%$ with each other. The $\mathrm{G}+\mathrm{C}$ content of the DNA of the isolates was $68 \cdot 9-69 \cdot 6 \mathrm{~mol} \%$.

A phylogenetic analysis of $16 \mathrm{~S}$ rDNA sequences indicated that both of the isolates are related to the type strain of L. albidocapillata and members of the genus Saccharothrix, Saccharothrix waywayandensis and Saccharothrix aerocolonigenes subsp. staurosporea (Fig. 3). The new isolates exhibit morphological and chemotaxonomic characteristics that are typical of the genus Saccharothrix as follows: a type III cell wall (the meso-isomer of diaminopimelic acid, and rhamnose and galactose in whole-cell hydrolysates), a major menaquinone of MK-9 $\left(\mathrm{H}_{4}\right)$, a phospholipid type PII pattern (phosphatidylethanolamine as a diagnostic phospholipid) and well-developed aerial and substrate mycelia that fragment into rod-shaped elements. The chemical composition of the genus Lentzea, except for the major menaquinone and the composition of cell wall sugars, is also coincident with that of the genus Saccharothrix (Yassin et al., 1995; Labeda et al., 1984). It has previously been reported that the only and type strain of genus Lentzea, L. albidocapillata, contained MK-9 as a major menaquinone and had no characteristic sugars (Yassin et al., 1995). However, our analysis showed that L. albidocapillata contained MK- $9\left(\mathrm{H}_{4}\right)$ as a predominant menaquinone, and had galactose and rhamnose as characteristic whole-cell sugars. The combination of morphological, chemotaxonomic and phylogenetic data support the proposal that L. albidocapillata should be transferred to the genus Saccharothrix. L. albidocapillata shows a level of 16S rDNA sequence similarity of $98 \cdot 1 \pm 0 \cdot 1 \%$ to its phylogenetic neighbours, $S$. waywayandensis and Saccharothrix aerocolonigenes subsp. staurosporea. $L$. albidocapillata is differentiated from Saccharothrix waywayandensis and Saccharothrix aerocolonigenes by its pathogenic properties, $\mathrm{G}+\mathrm{C}$ base composition, utilization of citrate and lactate, ability to liquefy gelatin and acid production from D-mannose, melibiose, D-raffinose and salicin (Labeda, 1986; Labeda \& Lyons, 1989).

The new isolates are readily distinguished from the type strain of L. albidocapillata on the basis of the production of violet-coloured substrate mycelium, fatty acid profiles (Table 1), physiological properties (Table 2) and low DNA-DNA hybridization values of $43 \pm 0.3 \%$. The isolated strains differ from Saccharothrix waywayandensis and Saccharothrix aerocolonigenes in utilization of citrate and oxalate, and in acid production from inositol, melibiose, rhamnose, salicin, sucrose and xylose (Labeda, 1986; Labeda \& Lyons, 1989). Thus, the isolates merit recognition as a new species of the genus Saccharothrix. The isolates show a high similarity in 
Table 2. Differential characters of the new isolates and of the type strain of L. albidocapillata

\begin{tabular}{|c|c|c|c|}
\hline Character & $\begin{array}{c}\text { Strain } \\
\text { LM 036 }^{\mathrm{T}}\end{array}$ & $\begin{array}{l}\text { Strain } \\
\text { LM } 044\end{array}$ & $\begin{array}{l}\text { L. albidocapillata } \\
\text { IMSNU } 21253^{\mathrm{T}}\end{array}$ \\
\hline \multicolumn{4}{|l|}{ Use of sole carbon sources: } \\
\hline Salicin & + & + & - \\
\hline Lactate & + & + & - \\
\hline Malate & - & - & + \\
\hline Oxalate & - & - & + \\
\hline \multicolumn{4}{|l|}{ Acid produced from: } \\
\hline D-Cellobiose & - & - & + \\
\hline D-Fructose & + & - & + \\
\hline D-Galactose & + & - & + \\
\hline D-Glucose & + & - & + \\
\hline Maltose & - & - & + \\
\hline L-Rhamnose & - & - & + \\
\hline Sucrose & - & - & + \\
\hline D-Trehalose & - & - & + \\
\hline D-Xylose & - & - & + \\
\hline Adonitol & - & - & + \\
\hline meso-Inositol & - & - & + \\
\hline D-Mannitol & - & - & + \\
\hline \multicolumn{4}{|l|}{ Hydrolysis of: } \\
\hline Gelatin & + & + & - \\
\hline \multicolumn{4}{|l|}{ Growth on: } \\
\hline $\mathrm{NaCl}(4 \%)$ & + & - & + \\
\hline Thallium acetate $(0.01 \%)$ & - & - & + \\
\hline \multicolumn{4}{|l|}{ Resistance to: } \\
\hline Vancomycin $(30 \mu \mathrm{g})$ & + & + & - \\
\hline \multicolumn{4}{|l|}{ Antibiotic activity against: } \\
\hline Bacillus subtilis & - & + & - \\
\hline Micrococcus luteus & - & + & - \\
\hline Streptomyces murinus & - & + & - \\
\hline Staphylococcus aureus & - & + & - \\
\hline Aspergillus niger & - & + & - \\
\hline Candida albicans & - & + & - \\
\hline Saccharomyces cervisiae & - & + & - \\
\hline
\end{tabular}

genotypic characters, whereas they exhibit a difference in ability to produce an antibiotic, in amount of $\mathrm{i}-\mathrm{C}_{14: 0}, \mathrm{i}-\mathrm{C}_{16: 1}, \mathrm{C}_{16: 1}, \mathrm{C}_{16: 0}$ and $\mathrm{C}_{18: 1}$ fatty acids, in acid production from $\mathrm{D}$-fructose, $\mathrm{D}$-galactose and D-glucose, and in growth with $4 \% \mathrm{NaCl}$.

On the basis of cultural and physiological properties, fatty acid profiles and the levels of DNA-DNA relatedness, we propose new species of the genus Saccharothrix, Saccharothrix violacea sp. nov. and Saccharothrix albidocapillata comb. nov. The emended description of Saccharothrix albidocapillata below is based on data taken from the original descriptions (Yassin et al., 1995) and our own studies.

\section{Description of Saccharothrix violacea sp. nov.}

Saccharothrix violacea (vi.o.la.ce'a. L. adj. violaceus violet; M.L. adj. violacea violet-coloured).
Forms a violet substrate mycelium and a white aerial mycelium. Reddish-brown pigment is produced. Melanin pigment is not produced. Aerial mycelium fragments into rod-shaped elements. Aerobic, catalaseand urease-positive, oxidase-negative. Nitrate is not reduced to nitrite. $\mathrm{H}_{2} \mathrm{~S}$ is produced. Growth occurs at $10-37^{\circ} \mathrm{C}$. No growth occurs at $42{ }^{\circ} \mathrm{C}$. Utilizes L-arabinose, D-cellobiose, D-fructose, D-galactose, D-glucose, D-lactose, maltose, D-mannose, melibiose, L-rhamnose, salicin, sucrose, D-trehalose, D-xylose, adonitol, meso-inositol, D-mannitol, acetate, fumarate, $\alpha$-ketoglutarate, lactate, malonate, propionate, pyruvate and succinate as carbon sources. Gelatin liquefaction occurs. Arbutin, DNA, aesculin, hypoxanthine and tyrosine are decomposed. Casein, hippurate and starch are hydrolysed. Acid is produced from L-arabinose, D-fructose, D-galactose, D-glucose, D-lactose and L-ribose. Growth occurs in the presence of $4 \% \mathrm{NaCl}$ and $0 \cdot 01 \%$ lysozyme. Does not utilize 


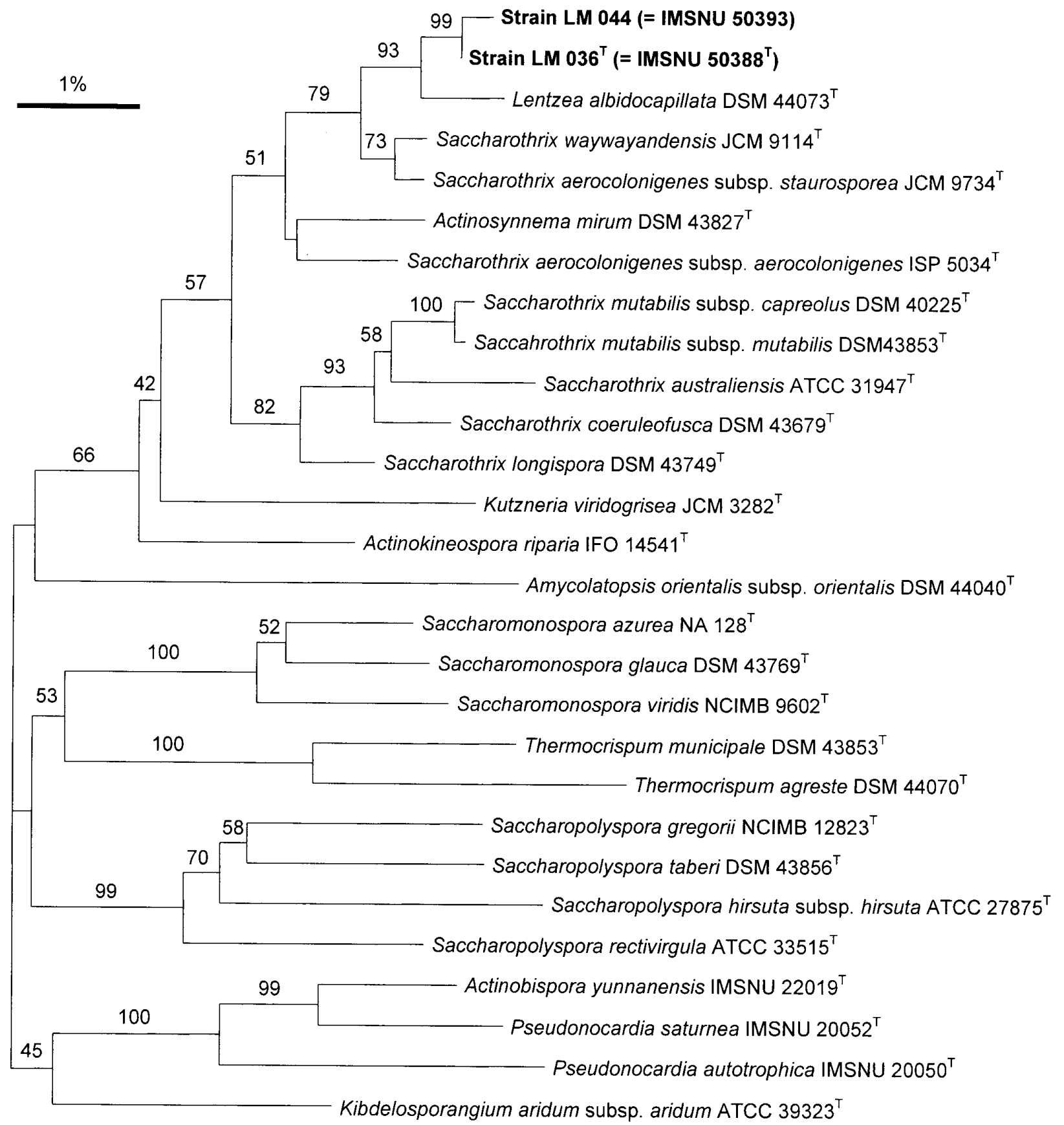

Fig. 3. Phylogenetic tree showing the relationship of the isolates and related taxa of the family Pseudonocardiaceae. Bootstrap values above $40 \%$ (based on percentages of 1000 replications) are indicated at the branching points. The scale bar indicates 1 nucleotide substitution per 100 nucleotides.

inulin, D-melezitose, methyl $\alpha$-D-glucoside, methyl $\alpha$-D-mannoside, D-raffinose, dulcitol, 2,3-butanediol, meso-erythritol, 1,2-propanediol, D-sorbitol, D-xylitol, benzoate, citrate, formate, malate, maleate, oxalate or tartarate as carbon sources. Adenine, guanine and xanthine are not decomposed. No growth occurs in the presence of $0.01 \%$ thallium acetate. No acid is produced from D-cellobiose, maltose, D-mannose, melibiose, methyl $\alpha$-D-mannoside, L-rhamnose, salicin, sucrose, D-trehalose, D-xylose, adonitol, meso-inositol or D-mannitol. Susceptible to erythromycin, gentamicin, kanamycin, neomycin, novobiocin, rifampicin, streptomycin, tetracycline and tobramycin, but resistant to ampicillin, lincomycin and vancomycin. Type III cell wall (meso-diaminopimelic acid, galactose, mannose and rhamnose in whole-cell hydrolysates). Phospholipid profiles contain phosphatidylethanolamine, diphosphatidylglycerol, phosphatidyl- 
glycerol and phosphatidylinositol. The major menaquinone is MK-9 $\left(\mathrm{H}_{4}\right)$. Mycolic acids are absent. The predominant fatty acid is $\mathrm{i}-\mathrm{C}_{16: 0}(42.5 \%$ of total $)$. A considerable amount of $\mathrm{C}_{16: 1}(9 \cdot 6 \%), \mathrm{i}-\mathrm{C}_{15: 0}(7 \cdot 0 \%)$ and $10 \mathrm{Me}-\mathrm{C}_{16: 0}(8.0 \%)$ are also present. The $\mathrm{G}+\mathrm{C}$ content of the DNA is $69.6 \mathrm{~mol} \%$ (as determined by HPLC). Isolated from soils inside a gold mine cave in Kongju, Korea. The type strain is strain LM $036^{\mathrm{T}}$ $\left(=\mathrm{IMSNU} 50388^{\mathrm{T}}\right)$.

Additional comments. Morphological and cultural characteristics of strain LM 044 (=IMSNU 50393) are similar to those of the type strain of Saccharothrix violacea. Differs from the type strain of Saccharothrix violacea in acid production from D-fructose, D-galactose and D-glucose, and in growth with $4 \% \mathrm{NaCl}$. Shows antimicrobial activity against Bacillus subtilis, Micrococcus luteus, Streptomyces murinus, Staphylococcus aureus, Aspergillus niger, Candida albicans and Saccharomyces cervisiae. The fatty acids are predominated by $\mathrm{i}-\mathrm{C}_{16: 0}(35.1 \%)$, followed by $\mathrm{C}_{16: 0}$ $(19.4 \%)$ and $\mathrm{C}_{16: 1}(14.9 \%)$. Small amounts of $10 \mathrm{Me}-$ $\mathrm{C}_{16: 0}$ and $10 \mathrm{Me}-\mathrm{C}_{18: 0}$ acids are also present. The $\mathrm{G}+\mathrm{C}$ content of the DNA is $68.9 \mathrm{~mol} \%$ (as determined by HPLC). Isolated from soils inside a gold mine cave in Kongju, Korea.

\section{Emended description of Saccharothrix albidocapillata comb. nov. (Yassin et al. 1995)}

Saccharothrix albidocapillata (al.bi.do.ca.pil.la' ta. L. adj. albidus white; L. adj. capillatus hairy; M.L. fem. adj. albidocapillata white-haired, referring to the abundant whitish aerial hyphae).

Forms a yellow-yellowish-brown-coloured substrate mycelium and a whitish aerial mycelium. No soluble pigment is produced. Melanin pigment is not produced. Aerial mycelium fragments into rodshaped elements. Aerobic, Gram-positive, catalase-, phosphatase-, $\beta$-glucosidase-, $\beta$-galactosidase- and urease-positive. Oxidase-negative. Nitrate is not reduced to nitrite. $\mathrm{H}_{2} \mathrm{~S}$ is produced. Growth occurs at $20-37^{\circ} \mathrm{C}$. No growth occurs at $42{ }^{\circ} \mathrm{C}$. Utilizes L-arabinose, D-cellobiose, D-fructose, D-galactose, D-glucose, D-lactose, maltose, D-mannose, melibiose, L-rhamnose, sucrose, D-trehalose, D-xylose, adonitol, meso-inositol, D-mannitol, acetate, fumarate, gluconate, $\alpha$-ketoglutarate, malate, malonate, oxalate, propionate, pyruvate, succinate, iso-amylalcohol and paraffin as carbon sources. Arbutin, DNA, aesculin, hypoxanthine and tyrosine are decomposed. Casein, elastin, hippurate and starch are hydrolysed. Growth occurs in the presence of $4 \% \mathrm{NaCl}, 0.01 \%$ thallium acetate and $0.01 \%$ lysozyme. Acid is produced from L-arabinose, D-cellobiose, D-fructose, D-galactose, D-glucose, D-lactose, maltose, L-rhamnose, L-ribose, sucrose, D-trehalose, D-xylose, adonitol, meso-inositol and D-mannitol. Adenine, guanine and xanthine are not decomposed. Keratin and testosterone are not hydrolysed. Does not utilize inulin, D-melezitose, methyl $\alpha$-D-glucoside, methyl $\alpha$-D-mannoside, D- raffinose, salicin, dulcitol, 2,3-butanediol, meso-erythritol, 1,2-propanediol, D-sorbitol, D-xylitol, benzoate, citrate, formate, $m$-hydroxybenzoate, $p$-hydroxybenzoate, lactate, maleate, tartarate or adipate as carbon sources. Gelatin liquefaction does not occur. No acid is produced from inulin, D-mannose, D-melezitose, melibiose, methyl $\alpha$-D-mannoside, D-raffinose or salicin. Susceptible to erythromycin, gentamicin, kanamycin, neomycin, novobiocin, rifampicin, streptomycin, tetracycline, tobramycin and vancomycin, but resistant to ampicillin and lincomycin. Type III cell wall (meso-diaminopimelic acid, galactose, mannose and rhamnose in whole-cell hydrolysates). The major menaquinone is $\mathrm{MK}-9\left(\mathrm{H}_{4}\right)$. The polar lipids contain phosphatidylethanolamine, diphosphatidylglycerol, phosphatidylglycerol and phosphatidylinositol. The predominant fatty acid is $\mathrm{i}-\mathrm{C}_{16: 0}(28 \cdot 8 \%)$, followed by $\mathrm{C}_{16: 1}(13.5 \%)$, i- $\mathrm{C}_{15: 0}$ $(12 \cdot 5 \%)$ and ai- $\mathrm{C}_{15: 0}(10 \cdot 4 \%)$. Small amounts of $10 \mathrm{Me}-\mathrm{C}_{16: 0}$ are also present. Mycolic acids are absent. The $\mathrm{G}+\mathrm{C}$ content of the DNA is $68.6 \mathrm{~mol} \%$ (as determined by HPLC). Isolated from a tissue specimen taken from an abdominal mass in a patient suffering from peritoneal carcinomatosis. The type strain is strain DSM $44073^{\mathrm{T}}\left(=\mathrm{IMSNU} 21253^{\mathrm{T}}\right)$.

\section{ACKNOWLEDGEMENTS}

This work was supported by a research grant for the Research Center for Molecular Microbiology, Seoul National University, from the Korea Science and Engineering Foundation (KOSEF).

\section{REFERENCES}

Brosius, J., Palmer, J. L., Kennedy, J. P. \& Noller, H. F. (1978). Complete nucleotide sequence of a $16 \mathrm{~S}$ ribosomal RNA gene from Escherichia coli. Proc Natl Acad Sci USA 75, 4801-4805.

Collins, M. D., Goodfellow, M. \& Minnikin, D. E. M. (1982). Polar lipid composition in the classification of Arthrobacter and Microbacterium. FEMS Microbiol Lett 15, 299-302.

Embley, T. M., Smida, J. \& Stackebrandt, E. (1988). The phylogeny of mycolateless wall chemotype IV actinomycetes and description of Pseudonocardiaceae fam. nov. Syst Appl Microbiol 11, 44-52.

Felsenstein, J. (1985). Confidence limits on phylogenies: an approach using the bootstrap. Evolution 39, 783-791.

Felsenstein, J. (1993). PHYLIP (phylogeny inference package), version 3.5c. Department of Genetics, University of Washington, Seattle.

Gordon, R. E., Barnett, D. A., Handerhan, J. E. \& Pang, C. H.-N. (1974). Nocardia coeliaca, Nocardia autotrophica, and the nocardia strain. Int J Syst Bacteriol 24, 54-63.

Grund, E. \& Kroppenstedt, R. M. (1989). Transfer of five Nocardiopsis species to the genus Saccharothrix Labeda et al. 1984. Syst Appl Microbiol 10, 267-274.

Hasegawa, T., Lechevalier, M. P. \& Lechevalier, H. A. (1978). A new genus of the Actinomycetales, Actinosynnema gen. nov. Int J Syst Bacteriol 28, 304-310.

Hopwood, D. A., Bibb, M. J., Chater, K. F. \& 7 other authors (1985). Genetic Manipulation of Streptomyces: a Laboratory Manual. Norwich: John Innes Foundation. 
Jukes, T. H. \& Cantor, C. R. (1969). Evolution of protein molecules. In Mammalian Protein Metabolism, vol. 3, pp. 21-132. Edited by H. N. Munro. New York: Academic Press.

Korn-Wendisch, F., Rainey, F., Kroppenstedt, R. M., Kempf, A., Majazza, A., Kutzner, H. J. \& Stackebrandt, E. (1995). Thermocrispum gen. nov., a new genus of the order Actinomycetales, and description of Thermocrispum municipale sp. nov. and Thermocrispum agreste sp. nov. Int J Syst Bacteriol 45, 67-77.

Kroppenstedt, R. M. (1985). Fatty acid and menaquinone analysis of actinomycetes and related organisms. In Chemical Methods in Bacterial Systematics, pp. 173-199. Edited by M. Goodfellow \& D. E. Minnikin. London: Academic Press.

Labeda, D. P. (1986). Transfer of "Nocardia aerocolonigensis" (Shinobu and Kawasto 1960) Pridham 1970 into the genus Saccharothrix Labeda, Testa, Lechevalier, and Lechevalier 1984 as Saccharothrix aerocolonigensis sp. nov. Int J Syst Bacteriol 36, 109-110.

Labeda, D. P. \& Lechevalier, M. P. (1989). Amendment of the genus Saccharothrix Labeda et al. 1984 and descriptions of Saccharothrix espanaensis sp. nov., Saccharothrix cryophilis sp. nov., and Saccharothrix mutabilis comb. nov. Int $J$ Syst Bacteriol 39, 420-423.

Labeda, D. P. \& Lyons, A. J. (1989). Saccharothrix texasensis sp. nov. and Saccharothrix waywayandensis $\mathrm{sp}$. nov. Int J Syst Bacteriol 39, 355-358.

Labeda, D. P., Testa, R. T., Lechevalier, M. P. \& Lechevalier, H. A. (1984). Saccharothrix: a new genus of the Actinomycetales related to Nocardiopsis. Int J Syst Bacteriol 34, 426-431.

Lechevalier, M. P. \& Lechevalier, H. A. (1970). Chemical composition as a criterion in the classification of aerobic actinomycetes. Int $J$ Syst Bacteriol 20, 435-443.

Lechevalier, M. P., Stern, A. E. \& Lechevalier, H. A. (1981). Phospholipids in the taxonomy of actinomycetes. Zentbl Bakteriol Hyg Abt 1 Suppl 11, 111-116.

Lee, S. D., Kang, S.-O. \& Hah, Y. C. (2000a). Hongia gen. nov., a new genus of the order Actinomycetales. Int $J$ Syst Bacteriol 50, 191-199.

Lee, S. D., Kim, E. S. \& Hah, Y. C. (2000b). Phylogenetic analysis of the genera Pseudonocardia and Actinobispora based on 16S ribosomal DNA sequences. FEMS Microbiol Lett 182, 125-129.

Mac Faddin, J. F. (1980). Biochemical Tests for Identification of Medical Bacteria, 2nd edn. Baltimore: Williams \& Wilkins.

Mesbah, M., Premachandran, U. \& Whitman, W. B. (1989). Precise measurement of the $\mathrm{G}+\mathrm{C}$ content of deoxyribonucleic acid by high-performance liquid chromatography. Int J Syst Bacteriol 39, 159-167.

Minnikin, D. E. M. (1988). Isolation and purification of mycobacterial wall lipids. In Bacterial Cell Surface Techniques, pp. 125-135. Edited by I. C. Hancock \& I. R. Poxton. Chichester: Wiley.

Minnikin, D. E., Patel, P. V., Alshamaony, L. \& Goodfellow, M. (1977). Polar lipid composition in the classification of Nocardia and related bacteria. Int J Syst Bacteriol 27, 104-117.

Minnikin, D. E., Hutchinson, I. G., Caldicott, A. B. \& Goodfellow, M. (1980). Thin layer chromatography of methanolysates of mycolic acid-containing bacteria. J Chromatogr 188, 221-233.

Minnikin, D. E., O’Donnell, A. G., Goodfellow, M., Alderson, G., Athalye, M., Schaal, A. \& Parlett, J. H. (1984). An integrated procedure for the extraction of bacterial isoprenoid quinones and polar lipids. J Microbiol Methods 2, 233-241.
National Committee for Clinical Laboratory Standards. (1994). Performance Standards for Antimicrobial Disk Susceptibility Tests, 5th edn, Approved Standard M100-S5, vol. 14, no. 16. Villanova, PA: National Committee for Clinical Laboratory Standards.

Pridham, T. G. \& Gottlieb, D. (1948). The utilization of carbon compounds by some Actinomycetales as an aid for species determination. J Bacteriol 56, 107-114.

Saddler, G. S., Tavecchia, P., Lociuro, S., Zanol, M., Colombo, E. \& Selva, E. (1991). Analysis of madurose and other actinomycete whole cell sugars by gas chromatography. J Microbiol Methods 14, 185-191.

Saitou, N. \& Nei, M. (1987). The neighbor-joining method: a new method for reconstructing phylogenetic trees. Mol Biol Evol 4, 406-425.

Sambrook, J., Fritsch, E. F. \& Maniatis, T. (1989). Molecular Cloning: a Laboratory Manual, 2nd edn. Cold Spring Harbor, NY : Cold Spring Harbor Laboratory.

Shirling, E. B. \& Gottlieb, D. (1966). Methods for characterization of Streptomyces species. Int J Syst Bacteriol 16, 313-340.

Stackebrandt, E., Kroppenstedt, R. M., Jahnke, K.-D., Kemmerling, C. \& Gürtler, H. (1994). Transfer of Streptosporangium viridogriseum (Okuda et al. 1966), Streptosporangium viridogriseum subsp. kofuense, and Streptosporangium albidum (Furumai et al. 1968) to Kutzneria gen. nov. as Kutzneria viridogrisea comb. nov., Kutzneria kofuensis comb. nov., and Kutzneria albida comb. nov., respectively, and emendation of the genus Streptosporangium. Int J Syst Bacteriol 44, 265-269.

Stackebrandt, E., Rainey, F. A. \& Ward-Rainey, N. L. (1997). Proposal for a new hierarchic classification system, Actinobacteria classis nov. Int $J$ Syst Bacteriol 47, 479-491.

Staneck, J. L. \& Roberts, G. D. (1974). Simplified approach to identification of aerobic actinomycetes by thin-layer chromatography. Appl Microbiol 28, 226-231.

Thompson, J. D., Higgins, D. G. \& Gibson, T. J. (1994). CLUSTAL $\mathrm{W}$ : improving the sensitivity of progressive multiple sequence alignment through sequence weighing, position-specific gap penalties and weight matrix choice. Nucleic Acids Res 22, 4673-4680.

Tomita, K., Nakakita, Y., Hoshino, Y., Numata, K. \& Kawaguchi, H. (1987). New genus of the Actinomycetales: Streptoalloteichus hindustanus gen. nov., nom. rev.; sp. nov., nom. rev. Int J Syst Bacteriol 37, 211-213.

Warwick, S., Bowen, T., McVeigh, H. \& Embley, T. M. (1994). A phylogenetic analysis of the family Pseudonocardiaceae and the genera Actinokineospora and Saccharothrix with 16S rRNA sequences and proposal to combine the genera Amycolata and Pseudonocardia in an emended genus Pseudonocardia. Int J Syst Bacteriol 44, 293-302.

Williams, S.T., Goodfellow, M., Alderson, E., Wellington, E. M. H., Sneath, P. H. A. \& Sackin, M. (1983). Numerical classification of Streptomyces and related genera. J Gen Microbiol 129, 1743-1813.

Yassin, A. F., Rainey, F. A., Brzezinka, H., Jahnke, K.-D., Weissbrodt, H., Budzikiewicz, H., Stackebrandt, E. \& Schaal, K. P. (1995). Lentzea gen. nov., a new genus of the order Actinomyceytales. Int J Syst Bacteriol 45, 357-363. 